\title{
A HISTORICAL PERSPECTIVE OF RESEARCH ON THE BIOLOGY OF AGING FROM NATHAN W. SHOCK
}

\author{
George T. BAKer, III $^{1 *}$ and W. ANDreW ACHENBaUm ${ }^{2}$ \\ 'Shock Aging Research Foundation, 14628 Carona Drive, Silver Spring, Maryland 20905 and ${ }^{2}$ Institute of \\ Gerontology, University of Michigan, Ann Arbor, Michigan 48109-2007
}

\begin{abstract}
This article describes some of the thoughts and the conceptual framework from which Nathan W. Shock prepared his last major presentation. This paper, written some 8 months following Dr. Shock's death on November 12,1989, is based upon his extensive notes and discussions with one of the authors (George T. Baker). This presentation in no way is meant to encapsulate the long and distinguished career of Nathan Shock, but rather to provide a glimpse of his perspectives on the development of the field of aging. Furthermore, we believe that the scientific principles concerning aging research laid out by $\mathrm{Dr}$. Shock in this publication are still valid today and may provide valuable insights for researchers in the field.
\end{abstract}

Key Words: aging research, testable hypotheses, mechanisms of aging

\section{A CRITICAL HISTORICAL ANALYSIS OF RESEARCH ON THE BIOLOGY OF AGING}

NATHAN W. SHock delivered his last major address, "Gerontology, the Study of AgingPast and Future," at the July 1989 Gordon Research Conference on the Biology of Aging. Four months beforehand, Shock began to review the historical development of biogerontology with the first author; he continued to refine his opinions until his death in November 1989. Shock used as his database references to the papers and works cited in the third edition of Alex Comfort's The Biology of Senescence (1979). And although his choice of this particular database was as much for convenience as for its comprehensiveness, it should be mentioned that Shock has at his disposal over 1000 volumes and 27000 reprints in his personal library, which is now housed in the archives of the Bentley Historical Library at the University of Michigan. It should also be remembered that for nearly half a century Shock meticulously reviewed virtually every publication in the field of gerontology for his Classified Bibliography of Gerontology and Geriatrics (1951a, 1957a, 1963) and later for the Shock Index, which was regularly published in the Journal of Gerontology.

\footnotetext{
*The preparation of this manuscript was conducted while GTB was a Visiting Scholar at the Institute of Gerontology at the University of Michigan, Ann Arbor, MI.
} 
Moreover and most critically, each publication was judged more on its particular merit than on the reputation of its author(s). The list by its very nature is highly restrictive but by no means arbitrary. Each citation represented a specific finding, novel approach, or conceptually sound idea applicable to the development of the field of biogerontology. The list of 201 publications Shock selected is reproduced as an appendix to this paper.

Not surprisingly, the list reflects Shock's unwavering commitment to high scientific standards. "Good" science to him meant raising important questions, generating solid data, and evaluating results through tough peer review. At least two other criteria, manifest in Baker's conversations with his friend and a review of Shock's published papers, influenced his selections. On the one hand, Shock singled out publications that serve(d) as building blocks for future work, well-publicized efforts that stood up to the test of time. On the other hand, Shock valued creativity in publications-ones that conveyed novel approaches, challenged the commonplace, and enabled other investigators to break new ground. Shock's list underlines the durabilty of six axioms of aging research he long had advocated:

\section{NATHAN W. SHOCK'S SIX AXIOMS FOR AGING RESEARCH}

1. Give me a testable hypothesis. It is worth a thousand theories!

2. Formulate questions to address basic mechanisms of aging and design scientifically rigorous protocols to examine those questions!

3. Focus research on the processes of aging over the entire life span. Studies on older individuals may tell one much about diseases in later life but are not likely to yield information about the basic mechanisms of aging!

4. Aging and disease are not synonymous! There are processes of aging and etiologies of disease. The relationships between the two are important but not inevitable!

5. Aging is a dynamic equilibrium! The rates of aging differ for various systems in any given organism, however, it is the whole organism that ages and dies!

6. Well-documented observations and good scientific data are timeless! Also, don't overlook studies in other scientific fields. Much of our knowledge in gerontology today is a by-product of nonaging research.

\section{TESTABLE HYPOTHESES ARE MORE VALUABLE THAN BUILDING THEORIES}

Shock was dismayed by the myriad theories of aging that did not specify careful causal relationships, and presentations of evidence that merely documented phenomena without seeking to explain them. "One of the difficulties that we encounter in gerontology, or the study of aging, is that we have a large mass of unstructured and unorganized observational data that has accumulated over the years as a by-product of other investigations" (Shock, 1962, p. 123). Rather than generate "grand" theories of senescence, Shock preferred to formulate testable hypotheses. "The goal of gerontologists is to reduce the dimensions of our ignorance about the basic mechanisms of aging by expanding knowledge about the interrelationships between variables and their relationships to the passage of time" (Baker and Shock, 1991).

The value of testing fundamental principles, argued Shock, was demonstrated in the way scientists showed that homeostasis was a basic mechanism of living organisms. Now viewed as a given, ideas about self-regulating processes advanced by Walter Cannon and 
Homer Smith were still not widely accepted in the 1940s when Shock wondered whether they applied specifically to the processes of aging. Shock's own work (1942; Shock $e t$ al., 1954) cited in the Appendix (henceforth noted A), as well as that of Adelman (A1970), Engle (A1944), Everitt (A1959), and Witschi (A1966) proved that the mechanism operated on a variety of levels in various species over time. The research publications of Medawar (A1940) and Maynard-Smith (A1958, A1965) had a similar impact: They added prestige to a fledgling enterprise with their questions and hypotheses.

The cumulative work on basic mechanisms in protein synthesis that led to the formulation of the "error" hypotheses of aging offers a more concrete example of how the successful testing of hypotheses can lead to conceptual breakthroughs in a scientific field. Concepts initially put forth by Szilard (A1959) and others on the potential role of mutational events over time eventually gave rise to the more specific "error" hypothesis by Medvedev (1962, A 1966) and Orgel (A1963). With the emergence of new immunological techniques, Gershon and Gershon (A1970) were indeed able to demonstrate the presence of altered enzyme proteins with age. Although the observed changes were eventually shown not due to errors in the primary structure of proteins as initially proposed, the testable hypothesis resulted in significant advances in our understanding of how molecular changes occur with advancing age.

Therefore, even testable hypotheses that were eventually disconfirmed proved valuable. This is one reason why Lansing (A1948, A1952, A 1964) is prominently featured on Shock's list. Lansing asked good questions and got researchers thinking, even if his initial interpretation of results would eventually be disproven. His concern for measuring the phenomena accurately, moreover, illustrates a second principle Shock held.

\section{MEASUREMENTS REPRESENT PHENOMENA-ONLY IF THE RESEARCH DESIGN IS SOUND}

Shock was very concerned about the individual and societal consequences of dramatic gains in life expectancy, but he understood that matters of social importance had to be dissected into discrete questions that could be subjected to rigorous analysis. "Research is a technical operation and not all questions can be answered in the form asked," Shock observed. "This formulation of questions and the design of adequately controlled procedures and observations are the essence of research" (1957b, p. 114).

Shock insisted that researchers design experimental protocols that negate age-related or incidental age-dependent variables such as disease or the presence of inhibitors or activators for molecular systems, artifacts due to extraction procedures, and the confounding effects of cohort and period. "The basic biological fact of aging is that the probability of death increases with age in a definite mathematical relationship" (Shock, 1961a, p. 654). Scientists thus should optimize environmental conditions for the entire lifespan of the species under investigation, recognizing that "optimal" conditions may differ at successive stages. To Shock, there was no "good" or "bad" animal model system per se. Bad experiments, however, suffered from flawed experimental paradigms and inappropriate techniques.

In this context, Shock praised Loeb's work (A1908) on the Drosophila, one of the first to measure rates of aging. Berg's analysis of nutrition's effects on longevity (A1960) is another classic, important for the way it quantified pathological influences. Shock admired works that tied together phenomenological information methodologically. 
Sacher (A1956, A 1958, A1959, A 1968, A1975, A 1976), for instance, was a good field biologist; his mathematics were not necessarily all that sophisticated, but they were robust enough to generate important anthropometric studies of longevity. Baker (A 1976), Banga (A 1957), Falzone et al. (A1959), and Goldstein (A1969) showed sensitivity to the nuances of how an experimental design might distort results.

Possibly the most vivid instance where attention to method and design advanced gerontologic thinking is evident in the work with in vitro cells. Based on experiments with chicken hearts, Carrel (A1912) had claimed that cells could live normally forever outside of the body. Hayflick and Moorhead (A1961) initiated a series of studies (Hart and Setlow, A 1974; Hayflick A1975; Holliday and Pugh, A1975) that disproved Carrel's hypothesis. Basic correlations of senescence found in vivo held in vitro. Demonstrating the importance of studying developments over time prompts a third axiom.

\section{STUDY MECHANISMS OF AGING, NOT JUST THE AGED}

Some gerontologists investigate only "old" subjects. Others choose not to differentiate between the processes of development and aging (Schroots, 1988; Yates, 1991). Early on, Shock opted for a centrist position: "In the broadest sense, problems of growth, development, and maturation are as much a part of gerontology as are those of atrophy, degeneration, and decline. However [attention] will be confined to changes that occur in later maturity and senescence" (1951b, p. 353).

Shock's work on the Berkeley child-development studies and in shaping the Baltimore Longitudinal Study of Aging convinced him that gerontologic research required comparisons at least at two points after maturity. Only this way could age changes be distinguished from age differences within a population. If results were to have general applicability to basic mechanisms of aging processes, moreover, Shock felt that research should be conducted on wild-type strains of various species. Highly inbred strains may be convenient for researchers because they exhibit less variance in any number of biochemical and physiological traits as well as survivorship, but they may not reflect normative processes of aging.

Many of the choices Shock made reflect his interest in mapping developmental changes and constructing life tables. The inclusion of Tanner (A1955) underlines Shock's interest in life transitions that have long-term effects. He esteemed the work of Pearl (A1927, A 1940), who did experiments to test hypotheses concerning rates of change in senescence. Similarly, Dublin et al. (A 1949) did more than measure life expectancy; these studies of mortality rates had a theoretical basis, which gave structure to future work.

The cluster of papers concerning basic mechanisms in various parts of the organism aptly tie together Shock's first three axioms. The pathways into neurobiology illuminated by Finch (A1972, A1976); Walford's descriptive studies of autoimmunity (A1962); and the work of Makinodan (Makinodan and Peterson, A 1966; Mackinodan et al., 1971 a,b), Price (A1971), Burnet (A1961, A 1970), and their colleagues on immunology all attest to the need for collaborative teams of specialists who have the complementary skills needed to do gerontologic research. The work on free radicals generated by Harman's laboratories (A1955, A1961, A1965, A1968, A 1971) and others (Kohn and Rollerson, A1960; Kohn, A1971) fits this pattern: A unified concept explained mechanistically the morphological, biological, and physiological processes of aging in a series of testable hypotheses. Their work strengthened the next rule. 


\section{AGING IS NOT A DISEASE}

"Perhaps one of the most useful contributions of gerontologic research has been the demonstration that aging is not necessarily associated with deterioration and disease" (Shock, 1961b, p. 16). Shock considered this simple observation the sine qua non of his research career. Chronic disease and aging were synonymous in many minds, he felt, not just because of stereotypes deeply rooted in the culture (Achenbaum and Kusnerz, 1978), but because those who professionally deal $(t)$ with late-life problems saw mainly elderly people who suffered some debility. To demonstrate that aging was not a disease sui generis, Shock pointed to basic research that bolstered his position.

Lorand's pioneering work (A1904) and Sheldon's (A1949) merit attention in this regard. Not only did they question the inevitability of senility, but they asked key questions that soon would dominate the field. Three decades ago, when Libow summarized existing evidence concerning differences between normative aging and disease processes (A1963), most professionals still hewed to outmoded concepts. Hence Gitman's (A1969) clinical guide that put disease of late life into diagnostic contexts and discussed "normal" phenomena of aging signaled an important shift in thought. And Shock praised early synthetic works-Birren (A1961) and Blumenthal (A1945)-for their emphasis on disentangling the effects of age and disease. This theme received a somewhat different statement in the next axiom.

\section{UNDERSTANDING BASIC MECHANISMS REQUIRES ATTENTION TO WHOLE ORGANISMS AND INTERSPECIES COMPARISONS}

Elaborating the theme of multidimensionality evident in Cowdry's landmark Problems of Aging (1939), Shock contended that "the problems of gerontology extend from questions of changes in enzyme conditions within individual cells to important social and economic problems of the interrelationships between aged people themselves and other members of society" $(1951 \mathrm{c}, \mathrm{p} .1)$. Scientists had to understand the physiological consequences with advancing age of a change and/or an alteration of the system they studied in relation to the whole animal. "Because of the diversity of rates of aging among different individuals as well as between different organ systems within the same individual, it is obvious that no specific answer can be given to the question, 'When does old age begin?" Shock observed. "Aging is a dynamic equilibrium. The individual animal at any age is a result of processes of accumulation and degradation that take place simultaneously" (1951d, pp. 1-2).

This is why Shock, a developmental physiologist, kept abreast of research in evolutionary biology. He evaluated results in terms of what an organism was evolutionarily designed to do. And he considered interspecies comparisons appropriate because aging was a universal, biological phenomenon. Significantly, his plans for an "ideal" research institute of gerontology in the 1950s included facilities for rearing and maintaining unicellular mechanisms, insects, dogs, cats, and so on (Shock, 1957b, p. 173).

Shock's emphasis on comparative analyses probably explains why many of the articles he considered notable concern organisms with which he had little firsthand experience. Such diverse projects as Flower's early studies of molluscs (A1922) and tortoises (A1945), the Szabo work with snails (A1929), and Thung's anthropometric analyses (A1962) all dealt with issues of growth and longevity. The more comparative baselines available to chart basic mechanisms and rates of aging, the more likely scholars would comprehend 
"natural" aging. Similarly, Shock's interest in research on inheritance-Jalavisto (A1950), Kallman and Sander (A1948), and Rockstein (A1958)_was yet another pathway for examining intraspecies differentials in rates of change at the genetic and organic levels. That this pioneering work has been refined by subsequent scholars did not diminish its value to Shock.

\section{SOLID DATA DO NOT LOSE VALUE BECAUSE THEY ARE OLD; A GENUINE SCIENTIFIC SPIRIT NEVER FADES}

It is revealing that only $19 \%$ of the 201 articles on Shock's list of major publications that facilitated biogerontology's development were published before 1939. This was the year that Cowdry's Problems of Aging appeared; Shock called the volume the first "modern" work of this emerging scientific field. Almost $60 \%$ of the works were published before 1959 , when the first of the three handbooks of aging prepared by the Inter-University Training Project in Social Gerontology were issued. One might quibble about the historical representativeness of Shock's list-he was, after all, using a data base already 10 years old at a time when some claimed that "knowledge in biomedicine has a doubling rate of approximately three years" (Schneider and Rowe, 1990, p. xvii). But more than most, Shock knew that the truly important questions in gerontology were perennial favorites. A review of the abstracts of the $1940 \mathrm{~s}$, moreover, indicated why breadth of vision was indispensable:

A good share of our knowledge about aging has come from studies where age data were a by-product of other research programs. Furthermore, many articles appear as a single contribution from many different laboratories throughout the country. Relatively few originate from laboratories where aging is a major concern. (Shock, 1951c, p. 75)

Regardless of where it is done, attention to fundamental issues, exemplary research designs, and peer review are essential for gerontologic progress.

No wonder, then, that the list compiled by one of gerontology's truly cosmopolitan scientists should include publications by so many international scholars. The very eclecticism of references has didactic value. The mention of Crocker's work on aging in plants (A1939) serves to remind us that early ideas about "senescence" came from botany; the multiple references to Lack's work with birds (A1943, A1954) attest to a scholar's voracious appetite to learn as much about aging as possible. Yet Nathan Shock was no amateur: Even one extended conversation with Shock communicated his disdain for much that passed as "research" in some areas of gerontologic expertise. Nor was Shock the type to express his hopes for gerontology in teleological terms. As this list indicates, Shock put his faith in good research because common sense and years of experience persuaded him that solid, basic work would yield the most useful gerontologic science.

\section{REFERENCES}

ACHENBAUM, W.A. and KUSNERZ, P.A. Images of Old Age in America, 1790 to the Present, Institute of Gerontology, Ann Arbor, MI, 1978.

BAKER, G.T., III and SHOCK, N.W. Theoretical concepts governing gerontological research. In: Potential for Nutritional Modulation of Aging Processes, Ingram, D.K., Baker, G.T., III, and Shock, N.W. (Editors), pp. 315, Food and Nutritional Press, Westport, CT, 1991.

COMFORT, A. The Biology of Senescence. 3rd ed. Elsevier, New York, NY, 1979. 
COWDRY, E.V. (Editor). Problems of Aging. The Williams and Wilkins Co., Baltimore, MD, 1939.

MEDVEDEV, Z.A. Aging at the molecular level and some speculations concerning maintaining the functioning of systems for replicating specific mancomolecules. In: Biological Aspects of Aging, Shock, N.W. (Editor), pp. 255-266, Columbia University Press, New York, NY, 1962.

SCHNEIDER, E.L. and ROSE, J.W. (Editors). Handbook of the Biology of Aging. 3rd ed. Academic Press, New York, NY, 1990.

SCHROOTS, J.J.F. On growing, formative change, and aging. In: Emergent Theories of Aging. Birren, J.E. and Bengtson, V.L. (Editors), Springer, New York, NY, 1988.

SHOCK, N.W. A Classified Bibliography of Gerontology and Geriatrics. Stanford University Press, Stanford, CA, 1951a.

SHOCK, N.W. Gerontology (later maturity). Annu. Rev. Psychol. 11, 353-366, $1951 \mathrm{~b}$.

SHOCK, N.W. Trends in Gerontology. Stanford University Press, Stanford, CA, $1951 \mathrm{c}$.

SHOCK, N.W. A Classified Bibliography of Gerontology and Geriatrics. Supplement One, 1949-1955. Stanford University Press, Stanford, CA, 1957a.

SHOCK, N.W. Trends in Gerontology. 2d ed. Stanford University Press, Stanford, CA, 1957b.

SHOCK, N.W. Current concepts of the aging process. JAMA 175, 654-656, 1961 a.

SHOCK, N.W. The role of research in solving the problems of the aged. Gerontologist 1, 14-16, 1961b.

SHOCK, N.W. The science of gerontology. In: Proceedings of Seminars, 1959-1961: Duke University Council on Gerontology, Jeffers, F.C. (Editor), Duke University, Durham, NC, 1962.

SHOCK, N.W. A Classified Bibliography of Gerontology and Geriatrics. Supplement Two, 1956-1961. Stanford University Press, Stanford, CA, 1963.

SHOCK, N.W., GREULICH, R.C., ANDRES, R., ARENBERG, D., COSTA, P.T., JR., LAKATTA, E.G., and TOBIN, J.D. Normal Human Aging: The Baltimore Longitudinal Study of Aging. NIH Publ. No. 84-2450. U.S. Government Printing Office, Washington, DC, 1984.

YATES, F.E. The sorcerer's apprentice. In: Metaphors of Aging, Birren, J.E., Kenyon, G. and Schroots, J.J.F. (Editors), Springer, New York, NY, 1991.

\section{APPENDIX: THE SHOCK LIST}

ADELMAN, R.C. Age-dependent effects in enzyme induction-a biochemical expression of aging. Exp. Gerontol. 6, 75-88, 1970.

ASLAN, A. Eine nue Methode zur Prophylaxe und Behandlung des Alterns mit Novocain. Therapiewoche 7, 14-22, 1956.

BAKER, G.T. Insect flight muscle: Maturation and senescence. Gerontology 22, 334-362, 1976.

BANGA, I. Der Effekt der schwachen organischen Sauren auf die Rattenschwanz-Kollagen-fasern von jungen und altern Tieren. Gerontologia 1, 325-346, 1957.

BENEDICT, F.G., and ROOT, H.F. The potentialities of extreme old age. Proc. Natl. Acad. Sci. U. S. A. 20, 389, 1934.

BERG, B.N. Nutrition and longevity in the rat. I: Food intake relative to size, health, and fertility. J. Nutr. 71, $242-254,1960$.

BERTOLINI, A.M. Modification of cellular enzyme systems during ageing. Gerontologia 6, 175-187, 1962.

BIRREN, J.E. (Editor) Handbook of Aging and the Individual. Chicago University Press, Chicago, IL, 1961.

BJORKSTEN, J. A common molecular basis for the aging syndrome. J. Am. Geriatr. Soc. 6, 740-748, 1958.

BLUMENTHAL, $\mathrm{H}$. The ageing process in the endocrine glands of the guinea pig. $I$. The influence of age, sex, and pregnancy on the mitotic activity and the histological structure of the thyroid, parathyroid, and adrenal glands. Arch. Pathol. 40, 284, 1945.

BOGOMOLETS, A.A. The Prolongation of Life. Duell, Sloan and Pearce, Inc., New York, NY, 1947.

BOOTHBY, W.M., BERKSON, J., and DUNN, H.L. Studies of the energy metabolism of normal individuals, Am. J. Physiol, 116-468, 1936.

BOURLIĖRE, F. Longévite moyenne et longévite maximum chez les vertébrés. Annee Biol. (Paris) 22, 10, 1946.

BRIZZEE, K.R., SHERWOOD, N., and TIMIRAS, P.S. A comparison of cell populations at various depth levels in cerebral cortex of young adult and aged Logan Evans rats. J. Gerontol. 23, 289-297, 1968.

BROCK, M.A. Ultrastructural studies on life cycle of a short-lived metazoan, Campanularia flexuosa. J. Ultrastruct. Res. 32, 118, 1970.

BRODY, S. The kinetics of senescence. J. Gen. Physiol. 6, 245, 1924.

BRODY, S. Bioenergetics and Growth. The Williams and Wilkins Co., Baltimore, MD, 1945. 
BURNET, F.M. The new approach to immunology. N. Engl. J. Med. 264, 24-34, 1961.

BURNET, F.M. Immunological Surveillance. Pergamon Press, Oxford, UK, 1970.

CARLSON, A.J. and HOELZEL, F. Apparent prolongation of the life-span of rats by intermittent fasting. $J$. Nutr. 31, 363-375, 1946.

CARREL, A. On the permanent life of tissues. J. Exp. Med. 15, 516, 1912.

CARREL, A. and EBELING, A.H. Antagonistic growth principles of serum and their relation to old age. $J$. Exp. Med. 38, 419-425, 1921.

CHEBOTATREV, D.F. Osnovyi Gerontologii. Medgiz, Moscow, 1969.

CHILD, C.M. A study of senescence and rejuvenation based on experiments with planarians. Arch. EntwMech. Org. 31, 537, 1911.

CHILD, C.M. The asexual cycle in Planaria velata in relation to senescence and rejuvenescence. Biol. Bull. Wood's Hole 25, 181, 1913.

CHILD, C.M. Asexual breeding and prevention of senescence in Planaria velata. Biol. Bull. Wood's Hole 26, $286,1914$.

CHILD, C.M. Senescence and Rejuvenescence. Chicago University Press, Chicago, IL, 1915.

CHILD, C.M. Physiological senescence in hydromedusae. Biol. Bull. Wood's Hole 34, 49, 1918.

CHVAPIL, M. and HRUZA, Z. The influence of aging and undernutrition on chemical contractility and relaxation of collagen fibres in rats. Gerontologia 3, 241-252, 1959.

CIUCA, A. and JUCOVSKI, V. Recherches concernant la determination de "L'ge biologique moyen." Riv. Expan. Gerontol. 4, 97-116, 1969.

CLARK, A.M. The relation of genome number to radio sensitivity in Habrobracon. Am. Nat. 91, 111-119, 1957.

COHN, A.E. and MURRAY, H.A. The negative acceleration of growth with age, as demonstrated by tissue culture. J. Exp. Med. 42, 175, 1925.

COMFORT, A. Absence of a Lansing effect in Drosophila subobscura. Nature 172, 83, 1953.

COMFORT, A. Biological aspects of senescence. Biol. Rev. 29, 284-329, 1954.

COMFORT, A. Mortality and the nature of age processes, Alfred Watson Memorial Lecture. J. Inst. Act. 84, 263-280, 1958.

COMFORT, A. Nutrition and longevity in animals. Proc. Nutr. Soc, 19, 125-129, 1960.

COMFORT, A. The prevention of ageing in cells. Lancet ii, 1325-1329, 1966.

COMFORT, A. Measuring the human aging rate. Mech. Ageing Devel. 2, 82-87, 1972.

COWDRY, E.V. In: Cowdry's Problems of Aging. Lansing, A.I. (Editor), The Williams and Wilkins Co., Baltimore, MD, 1952.

CROCKER, W. Aging in plants. In: Problems of Aging, Cowdry, E.V. (Editor). The Williams \& Wilkins Co., Baltimore, MD, 1939.

CROZIER, W.J. The growth of the shell in the lamellibranch Dosinia discus. Zool. Jb. (Anat.) 38, 577-583, 1914.

CROZIER, W.J. Growth of Chiton tuberculatus in different environments. Proc. Nat. Acad. Sci. U. S. A. 4, 325$328,1918$.

CURTIS, H.J. Biological mechanism underlying the ageing process. Science 141, 686-694, 1963.

DILMAN, V.M. Age-associated elevation of hypothalamic threshold of feedback control and its role in development, ageing, and disease. Lancet i, 1211-1219, 1971.

DUBLIN, L.I., LOTKA, A.J., and SPIEGELMAN, M. Length of Life: A Study of the Life Table. Ronald Press, New York, NY, 1949.

DUNOY, P.L. Cicatrization of wounds. J. Exp. Med. 24, 461, 1916.

DUNOY, P.L. Biological Time. Methuen, London, UK, 1936.

ENGLE, E.T. The menopause, an introduction. J. Clin. Endocrinol. 4, 567, 1944.

EVERITT, A.V. The effect of pituitary growth hormone on the aging male rat. J. Gerontol. 14, 415-424, 1959.

FALZONE, J.A., BARROWS, C.H., and SHOCK, N.W. Age and polyploidy of rat liver as measured by volume and D.N.A. content. J. Gerontol. 14, 2-8, 1959.

FINCH, C.E. Enzyme activities, gene function and aging in mammals. Exp. Gerontol. 7, 53, 1972.

FINCH, C.E. The regulation of physiological changes during mammalian aging. $Q$. Rev. Biol. 51, 49-83, 1976.

FLOWER, S.S. Longevity of molluscs. Cairo Sci. J. 10, 115, 1922.

FLOWER, S.S. Persistent growth in the tortoise, Testudo graeca, for 39 years, with other notes concerning the species. Proc. Zool. Soc. (Lond.) 114, 451, 1945.

FREMONT-SMITH, F. In: Aging and Levels of the Biological Organization, Brues, A.M. and Sacher, G.A. (Editors), Chicago University Press, Chicago, IL, 1965. 
FURTH, J., UPTON, A.C., CHRISTENBERRY, K.W. BENEDICT, W.H., and MOSHMAN, J. Some later effects in mice of ionizing radiation from an experimental nuclear detonation. Radiology 63, 562-570, 1954.

GERSHON, H. and GERSHON, D. Detection of inactive enzyme molecules in aging of the organism. Nature 227, 1214-1217, 1970.

GEY, G.O. Cellular gerontologic research. J. Gerontol. 7, 294, 1952.

GITMAN, L. Multiphasic Health Screening Center Manual. Brookdale Hospital Center, New York, NY, 1969.

GLINOS, A.D. and GEY, E.G. The effect of regeneration on the growth potential in vitro of rat liver at different ages. Cancer Res. 11, 164, 1951.

GOLDSTEIN, S. Survival of cultured cells in progeria. Lancet i, 424, 1969.

GREGERMAN, R.I. Adaptive enzyme responses in the senescent rat: Tryptophan peroxidase and tyrosine transaminase. Am. J. Physiol. 197, 63-64, 1959.

HALL, D.A. Age changes in the water content of human plasma. Gerontol. Clin. 10, 193-200, 1963.

HALL, D.A. The ageing of connective tissue. Exp. Gerontol. 3, 77-90, 1968.

HAMILTON, J.B. The role of testicular secretions as indicated by the effects of castration in man and by studies of pathological conditions and the short life span associated with maleness. Recent Prog. Horm. Res. 3, 257, 1948.

HAMILTON, W.D. The moulding of senescence by natural selection. J. Biol. 12, 12-45, 1966.

HARANGHY, L. and BALÄSZ, A. Aging and rejuvenation in planarians. Exp. Gerontol. 1, 77-84, 1964.

HARANGHY, L. and BALÁSZ, A., and BURG, M. Histological and histochemical analysis in mussels (Andonta) of the involution of the genitals. Proc. Ist Int. Congr. Hungarian Gerontologists (Budapest), 1962.

HARMAN, D. Ageing - a Theory Based on Free Radical and Information Theory. U.C.R.L. Publ. 3078. University of California, Berkeley, CA, 1955.

HARMAN, D. Prolongation of the normal life span and inhibition of spontaneous cancer by antioxidants. $J$. Gerontol. 16, 247-254, 1961.

HARMAN, D. The free radical theory of aging: Effects of age on serum copper levels. J. Gerontol. 20, 151-154, 1965.

HARMAN, D. Free radical theory of aging: Effect of free radical reaction inhibitors on the mortality rate of male $\mathrm{LAF}_{1}$ mice, J. Gerontol. 23, 476-485, 1968.

HARMAN, D. Free-radical theory of aging: Effect of amount and degree of unsaturation of dietary fat on mortality rate. J. Gerontol. 26, 451-456, 1971.

HARRISON, B.J. and HOLLIDAY, R. Senescence and the fidelity of protein synthesis in Drosophila. Nature 213, 990-991, 1967.

HART, R.W. and SETLOW, R.B. Correlation between deoxyribonucleic acid excision-repair and life-span in a number of mammalian species. Proc. Natl. Acad. Sci. U.S. A. 71, 2169-2173.

HAYFLICK, L. The limited in vitro lifetime of human diploid cells strains. Exp. Cell Res. 37, 614-636, 1965.

HAYFLICK, L. Cell biology of aging, Bioscience 25, 629-637, 1975.

HAYFLICK, L. and MOORHEAD, P.S. The serial cultivation of human diploid cell strains. Exp. Cell Res. 25, 585-621, 1961.

HOLLIDAY, R. Errors in protein synthesis and clonal senescence in fungi. Nature 221, 1224-1228, 1969.

HOLLIDAY, R. and PUGH, J.E. DNA modification mechanisms and gene activity during development. Science 187, 226-232, 1975.

HOLLINGSWORTH, D.R., HOLLINGSWORTH, J.W., BOGITCH, S., and KEELIN, R.J. Neuromuscular tests of aging in Hiroshima survivors. J. Gerontol. 24, 276-283, 1969.

HOLLINGSWORTH, J.W., ISHI, G., and CONRAD, R.A. Skin aging and hair graying in Hiroshima. Geriatrics 16, 27-36, 1961.

HOWELL, T. Multiple pathology in a septuagenarian. J. Am. Geriatr. Soc. 16, 760-762, 1968.

HRACHOVEC, J.P. Age changes in amino acid incorporation by rat liver microsomes. Gerontologia 15, 52-63, 1969.

HRACHOVEC, J.P. Inhibitory effect of gerovital $\mathrm{H} 3$ on rat liver monoamine oxidase. Proc. 25th Annu. Meet. Gerontol. Soc. (U.S.A.), p. 31, 1972.

HRŮZA, A. and FÁBRY, P. Some metabolic and endocrine changes due to long-lasting caloric under-nutrition. Gerontologia 1, 279-287, 1957.

HRŮZA, A., VRZALOVÁ, Z., HRABALOVÁ, A., and HLAVACCOVÁ, V. The effect of cooling on the speed of aging in collagen in vitro and in hibernation of the fat dormouse (Glis glis). Exp. Gerontol. 2, 29-36, 1966.

HUFELAND, C.W. Makrobiotik, oder der Kunst das menschliche Leben zu verlängern. Jena, Germany, 1798. 
JALAVISTO, E. The influence of parental age on the expectation of life. Rev. Med. Liege 5, 719, 1950.

JARVIK, L.F. and FALEK, A. Intellectual stability and survival in the aged. J. Gerontol. 18, 173-176, 1963.

JARVIK, L.F. and MILNE, J.F. Genesis and treatment of psychological disorders in the elderly. In: Aging. Vol. 2, Gershon, S. and Rasking, A. (Editors), Raven Press, New York, NY, 1975.

JENNINGS, H.S. Paramecium bursaria: Life history. Some relations of external conditions, past or present, to ageing and to mortality of exconjugants, with summary of conclusions on age and death. J. Exp. Zool. 99, 15, 1945.

KALLMAN, F.J. and SANDER, G. Twin studies on ageing and longevity. J. Hered. 39, 349, 1948.

KEYS, A. The age trend of serum concentration of cholesterol and of Sf 10-20 ("G") substance in rats. J. Gerontol. 7, 201-206, 1952.

KIRK, J.E. The acid of testosterone administration of the prostatic fluid in young, middle-aged and old individuals. J. Gerontol. 3, 98, 1948.

KOHN, R.R. Effects of antioxidants of lifespan of C57BL mice. J. Gerontol. 26, 378-380, 1971.

KOHN, R.R. and ROLLERSON, E. Aging of human collagen in relation to susceptibility to the action of collagenase. J. Gerontol. 15, 10-15, 1960.

KORENCHEVSKY, V. Natural relative hyperplasia and the process of aging. J. Pathol. Bacteriol. 54, 13, 1942.

KORENCHEVKSY, V. The longest span of life found in the records of centenarians in England and Wales. $B M J$ ii, $14,1947$.

KORENCHEVSKY, V., PARIS, S.K., and BENJAMIN, B. Treatment of senescence in female rats with thyroid hormones. J. Gerontol. 5, 120, 1950.

KORENCHEVSKY, V., PARIS, S.K., and BENJAMIN, B. Treatment of senescence in male rats with sex and thyroid hormones and desoxycorticosterone acetate. J. Gerontol. 8, 415, 1953.

KOTSOVSKY, D. The origin of senility. Am. J. Physiol. 90, 419, 1929.

KOUNTZ, W.B. Restoration of body function in the aged. J. Gerontol. 5, 385, 1950.

KROHN, P.L. Tissue transplantation techniques applied to the problem of the ageing of the organs of reproduction. Ciba Found. Colloquia on Aging 1, 141, 1955.

LABELLA, F.S. Pharmacological retardation of aging. Gerontologist 6, 46-50, 1966.

LABELLA, F.S. and PAUL, G. Structure of collagen from human tendon as influenced by age and sex. J. Gerontol. 20, 54-59, 1965.

LACK, D. The age of blackbirds. Br. Birds 36, 166, 1943.

LACK, D. The Natural Regulation of Animal Numbers. Oxford University Press, Oxford, UK, 1954.

LANDOWNE, M. Methods and limitation in studies of human organ function. Ciba Found. Colloquium on Ageing 3, 73-91, 1957.

LANG, A. Kleine biologische Beobachtungen ber die Weinbergschnecke (Helix pomatia L.). Viertelgjabr. Ges. Zurich 61, 488, 1896.

LANG, A. Über Vorversuche zu Untersuchungen ber die Variettenbildung von Helix bortensis and Helix nemoralis. Denkschr. d. med. Naturwiss. Ges. Jena II, 437-505, 1904.

LANG, A. Uber die Bastarde von Helix bortensis und Helix nemoralis, Eine Untersuchung zu experimentelle Verebunslebre. Fischer, Jena, Germany, 1908.

LANSING, A.I. Some effects of hydrogen ion concentration, total salt concentration, calcium and citrate on longevity and fecundity in the rotifer. J. Exp. Zool. 91, 195, 1942.

LANSING, A.I. The influence of parental age on longevity in rotifers. J. Gerontol. 3, 6, 1948.

LANSING, A.I. In: Cowdry's Problems of Aging, Cowdry, E.V. (Editor), The Williams and Wilkins Co., Baltimore, MD, 1952.

LANSING, A.I. Age variations in the cortical membranes of rotifers. J. Cell Biol. 23, 403-422, 1964.

LEAF, A. Youth in Old Age. McGraw-Hill, New York, NY, 1975.

LEHMAN, H.C. The longevity of the eminent. Science 98, 270, 1943.

LEOPOLD, A.C. Senescence in plant development. Science 134, 1727-1732, 1961.

LIBOW, L.S. In: Human Aging, a Behavioral and Biological Study, Birren, J.E., Butler, R.N., Greenhouse, S.W., Sokoloff, L., and Yarrow, M.R. (Editors), p. 37, USPHS 986, Bethesda, MD, 1963.

LINDOP, P.J. Shortening of life-span of mice as a function of age at irradiation. Gerontologia 3, 122-127, 1959.

LOEB, J. Über den Temperaturkoeffizienten für die Lebensdauer kaltblütiger Tiere usw. Pflugers Arch. 124, 411 , 1908.

LOEB, J. and NORTHROP, J.H. On the influence of food and temperature on the duration of life. J. Biol. Chem. 32, 103, 1917. 
LORAND, A. Quelques considérations sur les causes de sénilité. C. R. Soc. Biol. (Paris) 57, 500, 1904.

LOWRY, O.H. and HASTINGS, A.B. Quantitative histochemical changes in ageing. In: Cowdry's Problems of Aging, Lansing, A.I. (Editor), pp. 728-755, The Williams and Wilkins Co., New York, NY, 1952.

MAKINODAN, T., CHINO, F., LEVER, W.E., and BREWER, B.S. The immune systems of mice reared in clean and dirty conventional laboratory farms. J. Gerontol. 508-514, $1971 \mathrm{a}$.

MAKINODAN, T., PERKINS, E.A., and CHEN, M.G. Immunologic activity of the aged. Adv. Gerontol. Res. 3, 171-198, $1971 \mathrm{~b}$.

MAKINODAN, T. and PETERSON, W.J. Secondary antibody forming potential of mice in relation to age. Dev. Biol. 14, 96-111, 1966.

MARTIN, G.M., SPRAGUE, C.A., and EPSTEIN, C.J. Replicative lifespan of cultured human cells. Lab. Invest. 22, 86-91, 1970.

MASSIE, H.R., BAIRD, M.B., and WILLIAMS, T.R. Lack of increase in DNA crosslinking in Drosophila with age. Gerontologia 21, 73-80, 1975.

MASTERS, W.H. The female reproductive system. In: Cowdry's Problems of Aging, Lansing, A.I. (Editor), pp. 651-685, The Williams and Wilkins Co., Baltimore, MD, 1952.

MAYNARD-SMITH, J. Prolongation of the life of Drosophila subopscura by a brief exposure of adults to a high temperature. Nature 181, 956-958, 1958.

MAYNARD-SMITH, J. Ageing. Heredity 20, 147, 1965.

MCCANCE, R.A. and WIDDOWSON, A.M. A fantasy on ageing and the bearing of nutrition upon it. Ciba Found. Colloquia on Ageing 1, 186, 1955.

McCAY, C.M. In: Cowdry's Problems of Aging, Lansing, A.I. (Editor), The Williams and Wilkins Co., Baltimore, MD, 1952.

MCCAY, C.M. and CROWELL, M.F. Prolonging the lifespan. Sci. Mon. 39, 405-414, 1934.

MEADOW, N.D. and BARROWS, C.H. Studies on aging in a bdelloid rotifer. I. Effect of various culture systems on longevity and fecundity. J. Exp. Zool. 176, 303, 1971.

MEDAWAR, P.B. The growth, growth-energy and ageing of the chicken's heart. Proc. R. Soc. Lond. [Biol.] 129, 332-340, 1940.

MEDAWAR, P.B. Old age and natural death. Mod. Quart. 1, 30, 1945.

MEDVEDEV, Z.A. Protein Biosynthesis. Oliver and Boyd, London, UK, 1966.

METCHNIKOFF, E. The Nature of Man. Heinemann, London, UK, 1904.

METCHNIKOFF, E. La mort du papillon du murier-un chapitre de thanatologie. Ann. Inst. Pasteur, p. 477 , 1915.

MILDVAN, A.S. and STREHLER, B.L. A critique of theories of mortality. The Biology of Aging, AIBS Symp. 6, 216-235, 1960.

MINOT, C.S. The problem of age, growth, and death; a study of cytomorphosis, based on lectures at the Lowell Institute, March 1907, London. Moderne Probleme der Biologie (Jena), 1913.

NAGORNYI, A.V. Old Age and the Prolongation of Life. Sovietskaya Nauka, Moscow, 1948.

NANDY, K. and BOURNE, G.H. Effect of centrophenoxin on the lipofuscin pigments in the neurones of senile guinea-pigs. Nature 210, 213-314, 1966.

NASCHER, I. A noted case of longevity-John Shell, centenarian. Am. Med. 15, 151, 1920.

NEEDHAM, J. Biochemistry and Morpholgenesis. Cambridge University Press, Cambridge, UK, 1942.

NIKITIN, V.N. [Longevity]. Sci. \& Life (Moscow) 8, 27, 1954.

NORTHROP, J. The effect of prolongation of the period of growth on the total duration of life. J. Biol. Chem. 32, $123,1917$.

ONO, T., OKADA, S., and SUGAHARA, T. Comparative studies of DNA size in various tissues of mice during the aging process. Exp. Gerontol. 11, 127-132, 1976.

ORGEL, L.E. The maintenance of the accuracy of protein synthesis and its relevance to aging. Proc. Natl. Acad. Sci. U.S. A. 49, 517-521, 1963.

PEARL, R. On the distribution of differences of vitality among individuals. Am. Natl. 61, 113, 1927.

PEARL, R. Introduction of Medical Biometry and Statistics. 3rd ed. W.B. Saunders, Philadelphia, PA, 1940.

PINCUS, G. Measures of stress responsibility in younger and older men. Psychosom. Med. 12, 225, 1950.

PREHODA, R.W. Designing the Future-the Role of Technological Forecasting. Chilton, Philadelphia, PA, 1967.

PRICE, G.B. and ALBRIGHT, J.S. Cellular defects in immune responses of aging mice. Fed. Proc. 30(A), 526, 1971. 
ROBERTSON, T.B. and RAY, L.A. Experimental studies on growth, XI. The influence of pituitary gland tissue, tethelin, egg lecithin, and cholesterol upon the duration of life in the white mouse. J. Biol. Chem. 37, 427, 1919.

ROCKSTEIN, M. Heredity and longevity in the animal kingdom. J. Gerontol. 13(Suppl. 2), 7-13, 1958.

ROSS, R.H. Length of life and nutrition in the rat. J. Nutr. 75, 197-210, 1961.

SACHER, G.A. On the statistical nature of mortality, with especial reference to chronic radiation mortality. Radiology 67, 250-257, 1956.

SACHER, G.A. Entropic contributions to mortality and aging. In: Symposium on Inform. Theory Biol., Pergamon Press, Cambridge, UK, 1958.

SACHER, G.A. Relations of lifespan to brain weight and body weight in mammals. In: Ciba Found. Colloquia on Ageing, Wolstenholme, G.E.W. and O'Connor, M. (Editors), pp. 113-115, Churchill, London, UK, 1959.

SACHER, G.A. Molecular versus systemic theories on the genesis of aging. Exp. Gerontol. 3, 265-272, 1968.

SACHER, G.A. Maturation and longevity in relation to cranial capacity in hominid evolution. In: Primate Functional Morphology and Evolution, Tuttle, R. (Editor), pp. 417-442, Mouton, The Hague, Netherlands, 1975.

SACHER, G.A. Evaluation of the entropy and information terms governing mammalian longevity. In: Interdisciplinary Topics in Gerontology, Cutler, R.G. (Editor), Karger, Basel, Switzerland, 1976.

SAMIS, H.V. and WULFF, V.J. The template activity of rat liver chromatin. Exp. Gerontol. 4, 111-117, 1969.

SANADI, D.R. Decline of respiratory activity of myocardial mitochondria in senescence, Rec. Adv. Stud. Cardiac Struct. Metab. 3, 91-96, 1973.

SELYE, H. Calciphylaxis. Chicago University Press, Chicago, IL, 1962.

SELYE, H. and ALBERT, S. Age factor in responsiveness of pituitary and adrenal folliculoids. Proc. Soc. Exp. Biol. (N.Y.) 50, 159, 1942.

SHELDON, W.G. Reproductive behaviour of foxes in New York State. J. Mammal. 30, $236,1949$.

SHOCK, N.W. Standard values for basal oxygen consumption in adolescence. Am. J. Dis. Child. 64, $19,1942$.

SHOCK, N.W., WATKIN, D.M., and YIENGST, M.J. Age changes in renal function and basal oxygen consumption as related to total body water. Fed. Proc. 13, 136, 1954.

SILBERBERG, M. and SILBERBERG, R. Diet and life-span. Physiol. Rev. 35, 347-362, 1951.

SIMMS, H.S. and STILLMAN, N.P. Substances affecting adult tissue in vitro II. A growth inhibitor in adult tissue. J. Gen. Physiol. 20,621, 1936.

SIMMS, H.S. and STILLMAN, N.P. Substances affecting adult tissue in vitro III. A stimulant (the "A" factor) in serum ultrafiltrate involved in overcoming adult tissue dormancy. J. Gen. Physiol. 20, 649, 1937.

SÓBEL, H. Follow-up on mice exposed to 1.08 ATS oxygen in nitrogen for a substantial portion of lifespan. Aerospace Med. 41, 524-529, 1970.

SONNEBORN, T.M. Genetic studies on Stenostomum incaudatum n. sp. I. The nature and origin of differences in individuals formed during vegetative reproduction. J. Exp. Zool. 57, 57, 1930.

SONNEBORN, T.M. The delayed occurrence and total omission of endomixis in selected lines of Paramecium aurelia. Biol. Bull. Wood's Hole 74, 76, 1938.

SPIETH, W.E. In: Behaviour, Aging and the Nervous System, Welford, A.T. and Birren, J.E. (Editors), p. 366, Ch. C. Thomas, Springfield, IL, 1965.

STREHLER, B.L. Origins and comparisons of the effects of time and high energy radiations on living systems. Q. Rev. Biol. 34, 117-142, 1959.

SZABÓ, L. and SZABÓ, M. Lebensdauer, waschstum und altern, studiert bei der nacktschneckenart Agriolimax agrestis. Biol. Gen. 5, 95-118, 1929.

SZAFRAN, J. Age differences in sequential decisions and cardiovascular status among pilots. Aerospace Med. 36, 303-310, 1965.

SZILARD, L. On the nature of the aging process. Proc. Natl. Acad. Sci. U. S. A. 45, 30-45, 1959.

TANNER, J.M. Growth in Adolescence. Blackwell, Oxford, UK, 1955.

TAUCHI, H. On the fundamental morphology of the senile changes. Nagoya J. Med. Sci. 8, 1-22, 1961.

THUNG, P.J. In: Structural Aspects of Ageing, Bourne, G. (Editor), Pitman Medical, London, UK, 1962.

UPTON, A.C. Ionizing radiation and the aging process. J. Gerontol. 12, 306-313, 1957.

VERZAR, F. Vernderung der thermoelastrischen Eigenschaften von Sehnenfasern beim Altern. Experimentia 11, 230, 1955.

VERZAR, F. Aging of connective tissue. Gerontologia 1, 363-378, 1957.

VERZAR, F. Influence of ionizing radiation on the age reaction of collagen fibres. Gerontologia 3, 163-170, 1959 a. 
VERZAR, F. Note on the influence of procain (Novocain) para-aminobenzoic acid or diethylethanolamine on the ageing of rats. Gerontologia 3, 351-358, $1959 \mathrm{~b}$.

VERZAR, F. Lectures on Experimental Gerontology. Ch. C. Thomas, Springfield, IL, 1963.

VERZAR, F. Factors which influence the age reaction of collagen in skin. Gerontologia (Basel) 9, 209-221, 1964.

VISCHER, A.L. Old Age, its Compensations and Rewards. Allen and Unwin, London, UK, 1947.

VON HAHN, H.P. Failures of regulation and mechanisms as causes of cellular aging. Adv. Gerontol. Res. 3, 138,1971 .

VON HAHN, H.P. and VERZAR, F. Age-dependent thermal denaturation of DNA from bovine thymus. Gerontologia 7, 105-108, 1963.

WALFORD, R.L. Autoimmunity and aging. $J$. Gerontol. 17, 281-285, 1962.

WITSCHI, E. Endocrine aspects of aging in the guppy. I. The thyroid gland. Exp. Gerontol. 1, 315-330, 1966.

YIENGST, M., BARROWS, C., and SHOCK, N.W. Age changes in the chemical composition of muscle and liver in the rat. J. Gerontol. 14, 400-404, 1959.

ZEMAN, W. The neuronal ceroid-lipofuscinoses (Batten-Vogt syndrome)-a model for human aging? Adv. Geront. Res. 3, 147-170, 1971. 